\title{
Phytotherapy of chronic abdominal pain following pancreatic carcinoma surgery: a single case observation
}

This article was published in the following Dove Press journal:

International Journal of General Medicine

15 October 2012

Number of times this article has been viewed

\author{
Karl Rüdiger Wiebelitz \\ André-Michael Beer \\ Department of True Naturopathy, \\ Blankenstein Hospital, Hattingen, \\ Germany
}

\begin{abstract}
A patient with pancreatic carcinoma diagnosed in 2005 suffered from chronic abdominal pain 6 years later that did not respond to conventional pain treatment according to guidelines. Furthermore, several complementary medical approaches remained ineffective. In the long run, only an Iberis amara drug combination relieved pain sufficiently. The drug is registered in Germany for the indications irritable bowel syndrome and dyspepsia. The multi-target approach of this combination drug may account for the effectiveness under these fundamentally different pathophysiological conditions. No serious undesired effects have been described in the use of this drug for other indications and none were observed in this case.
\end{abstract}

Keywords: Iberis amara combination, early dumping syndrome, late dumping syndrome

\section{Introduction}

The treatment of gastrointestinal malignancies often requires major surgery, the consequences of which, along with the adverse effects of chemotherapy, pose serious therapeutic issues.

The patient discussed here suffered from pancreatic carcinoma diagnosed in 2005. The patient had undergone major surgery and six cycles of chemotherapy sessions 6 years prior to admission to our clinic. In addition to general loss of strength, chronic abdominal pain was a constant complaint and did not improve despite prolonged administration of morphine preparations.

After admission to the Department of True Naturopathy at Blankenstein Hospital, Hattingen, Germany, the patient was prescribed a naturopathic complex treatment. ${ }^{1}$ After several treatment attempts, the patient reacted positively only to an Iberis amara drug combination that is commonly used for functional gastrointestinal disorders. ${ }^{2}$

\section{Case presentation}

The 65-year-old patient had been operated on in September 2005 for a ductal pancreatic carcinoma (T1, N1, M0). The surgery included a cholecystectomy, partial gastrectomy with subtotal duodenopancreatectomy, and gastrojejunostomy. The patient then received, within the (European Study Group for Pancreatic Cancer) ${ }^{3}$ six cycles of adjuvant chemotherapy. The study demonstrated that fluorouracil plus folinic acid was equal in effect to gemcitabine and that chemotherapy alone is superior to combined radio-chemotherapy.

Although stationary aftercare in November 2010 found no evidence of tumor recurrence and was without major pathological findings, the patient had been suffering since the operation from postprandial epigastric pain, meteorism, and evening
Correspondence: Andre-Michael Beer Department of True Naturopathy,

Blankenstein Hospital, Im Vogelsang 5-II, D-45527 Hattingen, Germany

Tel +492324396487

Fax +492324396497

Email andre.beer@klinik-blankenstein.de 
hypoglycemia. At the time of naturopathic hospital admission, the patient complained of night sweats that had been occurring for several weeks. On physical examination, a soft abdomen with normal scar tissue was observed. Pain through palpitation was not present. No palpable resistance was detected. Peristalsis was active. Laboratory findings were unremarkable (before administration of the Iberis amara drug combination: leucocytes 3640/ $\mu \mathrm{L}$, hemoglobin $10.8 \mathrm{~g} /$ $\mathrm{dL}$, thrombocytes $200,000 / \mu \mathrm{L}$, international normalized ratio [INR] 1.08, aspartate transaminase [AST] $37 \mathrm{U} / \mathrm{L}$, alanine aminotransferase [ALT] $22 \mathrm{U} / \mathrm{L}$, gamma-glutamyl transpeptidase [GGT] $47 \mathrm{U} / \mathrm{L}$, urea $23 \mathrm{mg} / \mathrm{dL}$, creatinine $0.77 \mathrm{mg} / \mathrm{dL}$, lipase $11 \mathrm{U} / \mathrm{L}$; after 6 weeks of administration of the Iberis amara drug combination: leucocytes $4880 / \mu \mathrm{L}$, hemoglobin $12.2 \mathrm{~g} / \mathrm{dL}$, thrombocytes $159,000 / \mu \mathrm{L}$, INR 1.11, AST $38 \mathrm{U} / \mathrm{L}$, ALT $17 \mathrm{U} / \mathrm{L}$, GGT $24 \mathrm{U} / \mathrm{L}$, urea $20 \mathrm{mg} / \mathrm{dL}$, creatinine $0.65 \mathrm{mg} / \mathrm{dL}$, lipase $25 \mathrm{U} / \mathrm{L}$; after 9 months of administration of the Iberis amara drug combination: leucocytes $5930 / \mu \mathrm{L}$, hemoglobin $12.3 \mathrm{~g} / \mathrm{dL}$, thrombocytes

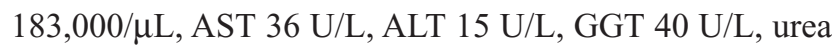
$16 \mathrm{mg} / \mathrm{dL}$, creatinine $0.82 \mathrm{mg} / \mathrm{dL}$, lipase $4 \mathrm{U} / \mathrm{L}$ ) except for some tumor marker values (before administration of the Iberis amara drug combination: carcinoembryonic antigen $10.7 \mathrm{ng} / \mathrm{mL}$ - marginally elevated [ $<3$; grey zone $3-10]$; carbohydrate antigen 19-9 within normal range), as were the esophagogastroduodenoscopy and computed tomography scans of the abdomen and upper gastrointestinal X-ray series. The last prescribed medication consisted of pancreas powder $(3 \times 40,000$ lipase units $)$, pantoprazole $(40 \mathrm{mg})$, and morphine drops $(2.0 \% ; 3 \times 12)$.

Both the postprandial pain as well as evening hypoglycemia were investigated in the pre-treating university hospital according to the valid scientific guidelines with respect to the possible differential diagnoses, and were interpreted as the consequence of early and late dumping syndrome. The university recommended the patient be transferred to Blankenstein Hospital for nutritional counseling and pain therapy with roborant hyperthermia treatment.

At the time of presentation in our department in July 2011, we observed that there had been no recurrence of the pancreatic carcinoma since 2005 and diagnosed dumping syndrome, severe night sweats, and psychophysical exhaustion. The patient suffered from frequent abdominal pain and received 15 drops of morphine before meals and ten drops of morphine after meals. Simultaneously, for purposes of quality of life, the patient received a mistletoe therapy, initially consisting of a phytotherapeutical mistletoe extract (Cefalektin ${ }^{\circledR}$; Cefak KG, Kempten, Germany) then of an anthroposophical mistletoe extract (Iscador ${ }^{\circledR}$; Weleda, Schwäbisch Gmünd, Germany). This latter treatment led to a rash and severe itching. Because of malaise, abdominal pain, and bloating, the pancreas powder dosage was reduced $(3 \times 25,000$ lipase units $)$, without affecting stool consistency or amount.

\section{Treatment}

As part of the naturopathic complex treatment, the patient received acupuncture, cupping therapy, and hyperthermia (hydroelectric baths) as well as medication.

The medication consisted initially (July 2011) of passion flower dry herb extract $(3 \times 425 \mathrm{mg})$, dry milk thistle extract (equivalent to $2 \times 140 \mathrm{mg}$ silymarin), a combined anthroposophical cardiac drug $(3 \times 10$ drops of Cardiodoron $^{\circledR}$; Weleda) and an anthroposophical mistletoe extract (AbnobaVISCUM ${ }^{\circledR}$ Pini; Abnoba Heilmittel GmbH, Pforzheim, Germany) in individualized doses. In September 2011, the patient received five hydroelectric baths. The analgesic medication consisted of a single dose of 25 drops of a combined phytotherapeutical tincture (Phytodolor ${ }^{\circledR}$; Steigerwald Arzneimittelwerk GmbH, Darmstadt, Germany) or an hourly dose of ten drops if required. Fresh potato juice was also prescribed, which unfortunately the patient tolerated poorly. Because of itching, even at lower doses, the mistletoe preparation was changed to another anthroposophical mistletoe extract (AbnobaVISCUM quercus) after 5 months.

Due to persistent abdominal complaints since October 6, 2011, Iberis amara drug combination drops $\left(3 \times 20\right.$; Iberogast ${ }^{\circledR}$, Steigerwald Arzneimittelwerk GmbH) were prescribed and this was found to be the only effective medication to decrease abdominal discomfort and maintain patient improvement. The improvement persisted throughout the follow-up period (9 months; July 19, 2012). The pain and its reduction were judged by clinical assessment and the patient's statements.

\section{Discussion}

Due to the patient's complex chronic medical history, it was surprising that the only medication that improved the abdominal pain was the phytotherapeutic Iberis amara drug combination.

The Iberis amara drug combination is a clinically proven, multi-target herbal product, consisting of nine plant extracts with a broad spectrum of activity in treating gastrointestinal complaints. ${ }^{4,5}$ This has been verified by a wide variety of experimental and clinical studies. Several effects are known to be attributable to single components of this drug combination 
(Angelica: antispasmodic; caraway: antispasmodic, antimicrobial; celandine: prokinetic, tone-raising; German chamomile: tone-modulating, anti-inflammatory; Iberis amara: tonemodulating, anti-inflammatory; licorice: antispasmodic, antiinflammatory; Melissa: antispasmodic, anti-inflammatory; milk thistle: digestive, antispasmodic; peppermint: antispasmodic, antiemetic).

Just a few minutes after taking the Iberis amara drug combination, normalization of disturbed gastric motility ${ }^{6}$ and thus significant improvement of the pain symptoms ${ }^{7}$ occurs. The Iberis amara drug combination increases the tone of the lower esophageal sphincter by forcing calcium to flow into the muscle cells, depolarizes smooth muscle cells in the small intestine,${ }^{8}$ decreases afferent sensitivity in the upper gastrointestinal tract, ${ }^{9}$ and reduces the amplitude and frequency of contraction waves. ${ }^{8}$ In addition, anti-ulcerogenic, ${ }^{10}$ antiinflammatory, ${ }^{11,12}$ antioxidant, ${ }^{13-15}$ pro-secretion, ${ }^{16}$ pain and acid-regulating, ${ }^{10}$ and spasmolytic effects ${ }^{17,18}$ within the entire gastrointestinal tract have also been documented. Synthesis of prostaglandin E2, inhibition of leukotrienes, increased mucin secretion, and reduced gastric acid formation contribute to the anti-ulcerogenic effect. Normalization of tumor necrosis factor-alpha, interleukin 1-beta, and intercellular adhesion molecule 1 levels, glutathione synthesis, and reduction of the myeloperoxidase activity produce the anti-inflammatory properties. Inhibition of the calcium flow in the muscle cells promotes a spasmolytic action in the gastric fundus and the colon. Activation of the L-type calcium channels enhances contraction of the antrum muscle cells. ${ }^{19}$ In all clinical trials, the positive effects of the drug ${ }^{20,21}$ and excellent patient tolerance of the Iberis amara drug combination have been exhibited, displaying a distinct advantage over allopathic drugs. ${ }^{22,23}$ The Iberis amara drug combination is the only drug approved in Germany for both the treatment of irritable stom$\mathrm{ach}^{24,25}$ and irritable bowel syndrome ${ }^{24,26}$ and is listed in the irritable bowel syndrome guidelines of the German Society for Digestive and Metabolic Diseases ${ }^{27}$ for both diseases.

While irritable bowel syndrome is characterized by abdominal pain with constipation and/or diarrhea in the absence of structural or biochemical causes, this patient's dumping syndrome is a typical consequence of operations involving removal of the pylorus. As in this case, after a Whipple's operation, the early stages of fluid intake in the small intestine lead to vasomotor disturbances. In the later stages, we found hypoglycemia with dizziness, tremors, and palpitations in response to an initial hyperglycemia due to rapid resorption in the small intestine in the absence of pre-digestion.
The multi-target approach of the Iberis amara drug combination apparently acts on several diseases with completely different pathophysiologies. The combined approach of different effects is a special feature of herbal medicines, which typically contain a mixture of ingredients. Apart from chemotherapy-induced mucositis in animal experiments ${ }^{28}$ and drug-induced gastrointestinal disease, ${ }^{29}$ there is very little published evidence outside the area of irritable bowel syndrome/dyspepsia that would allow comparison with the results presented here.

\section{Disclosure}

The authors report no conflicts of interest in this work.

\section{References}

1. Beer AM, Adler M, editors. Leitfaden Naturheilverfahren: für die ärztliche Praxis [Guide to Natural Remedies: for Medical Practice]. 1st ed. Munich: Elsevier; 2011. German.

2. Beer AM, Kuhlemann H, Kranzhoff M. Naturheilverfahren und konventionelle Medizin bei ausgewählten Magen-Darm-Erkrankungen [Naturopathic and conventional medicine in selected gastrointestinal disorders]. NaturaMed. 2000;15(6):18-26. German.

3. Neoptolemos JP, Moore MJ, Cox TF, et al. Effect of adjuvant chemotherapy with flurouracil plus folinic acid or gemcitabine vs observation on survival in patients with resected periampullary adnocarcinoma: the ESPAC-3 periampullary cancer randomized trial. JAMA. 2012;308(2):147-156.

4. Wegener T, Wagner $\mathrm{H}$. The active components and the pharmacological multi-target principle of STW 5 (Iberogast). Phytomedicine. 2006; 13 Suppl 5:20-35.

5. Kroll U, Cordes C. Pharmaceutical prerequisites for a multi-target therapy. Phytomedicine. 2006;13 Suppl 5:12-19.

6. Pilichiewicz AN, Horowitz M, Russo A, et al. Effects of Iberogast on proximal gastric volume, antropyloroduodenal motility and gastric emptying in healthy men. Am J Gastroenterol. 2007;102(6): $1276-1283$.

7. Madisch A, Melderis H, Mayr G, Sassin I, Hotz J. Ein Phytotherapeutikum und seine modifizierte Rezeptur bei funktioneller Dyspepsie. Ergebnisse einer doppelblinden plazebokontrollierten Vergleichsstudie [A plant extract and its modified preparation in functional dyspepsia. Results of a double-blind placebo controlled comparative study]. Z Gastroenterol. 2001;39(7):511-517. German.

8. Sibaev A, Yuece B, Kelber O, et al. STW 5 (Iberogast) and its individual herbal components modulate intestinal electrophysiology of mice. Phytomedicine. 2006;13 Suppl 5:80-89.

9. Müller MH, Liu CY, Glatzle J, et al. STW 5 (Iberogast) reduces afferent sensitivity in the rat small intestine. Phytomedicine. 2006;13 Suppl 5 100-106.

10. Khayyal MT, Seif-El-Nasr M, El-Ghazaly MA, Okpanyi SN, Kelber O, Weiser D. Mechanisms involved in the gastro-protective effect of STW 5 (Iberogast) and its components against ulcers and rebound acidity. Phytomedicine. 2006;13 Suppl 5:56-66.

11. Michael S, Abdel-Aziz H, Weiser D, Müller CE, Kelber O, Nieber K. Adenosine A2A receptor contributes to the anti-inflammatory effect of the fixed herbal combination STW 5 (Iberogast ${ }^{\mathbb{}}$ ) in rat small intestinal preparations. Naunyn Schmiedebergs Arch Pharmacol. 2011; 385(4):411-421.

12. Michael S, Kelber O, Hauschildt S, Spanel-Borowski K, Nieber K. Inhibition of inflammation-induced alterations in rat small intestine by the herbal preparations STW 5 and STW 6. Phytomedicine. 2009; 16(2-3):161-171. 
13. Schempp H, Weiser D, Kelber O, Elstner EF. Radical scavenging and anti-inflammatory properties of STW 5 (Iberogast) and its components. Phytomedicine. 2006;13 Suppl 5:36-44.

14. Germann I, Hagelauer D, Kelber O, et al. Antioxidative properties of the gastrointestinal phytopharmaceutical remedy STW 5 (Iberogast). Phytomedicine. 2006;13 Suppl 5:45-50.

15. Schempp H, Hippeli S, Weiser D, Kelber O, Elstner EF. Comparison of the inhibition of myeloperoxidase-catalyzed hypochlorite formation in vitro and in whole blood by different plant extracts contained in a phytopharmacon treating functional dyspepsia. Arzneimittelforschung. 2004;54(7):389-395.

16. Krueger D, Gruber L, Buhner S, et al. The multi-herbal drug STW 5 (Iberogast) has prosecretory action in the human intestine. Neurogastroenterol Motil. 2009;21(11):1203-e110.

17. Ammon HP, Kelber O, Okpanyi SN. Spasmolytic and tonic effect of Iberogast (STW 5) in intestinal smooth muscle. Phytomedicine. 2006; 13 Suppl 5:67-74.

18. Heinle H, Hagelauer D, Pascht U, Kelber O, Weiser D. Intestinal spasmolytic effects of STW 5 (Iberogast) and its components. Phytomedicine. 2006;13 Suppl 5:75-79.

19. Hohenester B, Rühl A, Kelber O, Schemann M. The herbal preparation STW5 (lberogast) has potent and region-specific effects on gastric motility. Neurogastroenterol Motil. 2004;16(6):765-773.

20. Saller R, Pfister-Hotz G, Iten F, Melzer J, Reichling J. Iberogast(r): Eine moderne phytotherapeutische Arzneimittelkombination zur Behandlung funktioneller Erkrankungen des Magen-Darm-Trakts (Dyspepsie, Colon irritabile) - von der Pflanzenheilkunde zur "Evidence Based Phytotherapy". Eine systematische Übersicht [Iberogast: a modern phytotherapeutic combined herbal drug for the treatment of functional disorders of the gastrointestinal tract (dyspepsia, irritable bowel syndrome) - from phytomedicine to "evidence based phytotherapy." A systematic review]. Forsch Komplementarmed Klass Naturheilkd. 2002;9 Suppl 1:1-20. German.

21. Rösch W, Liebregts T, Gundermann KJ, Vinson B, Holtmann G. Phytotherapy for functional dyspepsia: a review of the clinical evidence for the herbal preparation STW 5. Phytomedicine. 2006;13 Suppl 5: 114-121.

22. Raedsch R, Hanisch J, Bock P, Sibaev A, Vinson B, Gundermann KJ. Wirksamkeit und Unbedenklichkeit des Phytopharmakons STW 5 versus Metoclopramid bei funktioneller Dyspepsie unter Praxisbedingungen - eine retrolektive Kohortenstudie [Assessment of the efficacy and safety of the phytopharmacon STW 5 versus metoclopramide in functional dyspepsia - a retrolective cohort study]. Z Gastroenterol. 2007;45(10):1041-1048. German.
23. Rösch W, Vinson B, Sassin I. Vergleich der Wirksamkeit des pflanzlichen Therapeutikums STW 5 mit dem Prokinetikum Cisaprid bei Patienten mit funktioneller Dyspepsie des Dysmotilitätstyps. Eine randomisierte klinische Studie [A randomized clinical trial comparing the efficacy of a herbal preparation STW 5 with the prokinetic drug cisapride in patients with dysmotility type of functional dyspepsia]. Z Gastroenterol. 2002;40(6):401-408. German.

24. Allescher HD, Wagner H. STW 5/Iberogast: Multi-Target-Wirkung bei funktioneller Dyspepsie und Reizdarmsyndrom [STW 5/Iberogast: multi-target-action for treatment of functional dyspepsia and irritable bowel syndrome]. Wien Med Wochenschr. 2007;157(13-14):301-307. German.

25. von Arnim U, Peitz U, Vinson B, Gundermann KJ, Malfertheiner P. STW 5 , a phytopharmacon for patients with functional dyspepsia: results of a multicenter, placebo-controlled double-blind study. Am J Gastroenterol. 2007;102(106):1268-1275.

26. Madisch A, Holtmann G, Plein K, Hotz J. Treatment of irritable bowel syndrome with herbal preparations: results of a double-blind, randomized, placebo-controlled, multi-center trial. Aliment Pharmacol Ther. 2004;19(3):271-279.

27. Malfertheiner P, Holtmann G, Peitz U, et al; Teilnehmer der Leitlinien-Konferenz der Deutschen Gesellschaft für Verdauungs- und Stoffwechselkrankheiten. Leitlinien der Deutschen Gesellschaft für Verdauungs- und Stoffwechselkrankheiten zur Behandlung der Dyspepsie [Guidelines of the German Society of Digestive and Metabolic Diseases for treatment of dyspepsia]. Z Gastroenterol. 2001;39(11): 937-956. German.

28. Wright TH, Yazbeck R, Lymn KA, et al. The herbal extract, Iberogast, improves jejunal integrity in rats with 5-Fluorouracil (5-FU)-induced mucositis. Cancer Biol Ther. 2009;8(10):923-929.

29. MacLean N, Hübner-Steiner U. Behandlung arzneimittelbedingter Magen-Darm-Beschwerden. Doppelblindstudie zur Wirksamkeit von Iberogast im Vergleich zu Plazebo [Treatment of drug-induced gastrointestinal disorders. Double-blind study of the effectiveness of Iberogast compared to placebo]. Fortschr Med. 1987;105(12):239-242. German.
International Journal of General Medicine

\section{Publish your work in this journal}

The International Journal of General Medicine is an international, peer-reviewed open-access journal that focuses on general and internal medicine, pathogenesis, epidemiology, diagnosis, monitoring and treatment protocols. The journal is characterized by the rapid reporting of reviews, original research and clinical studies across all disease areas.

\section{Dovepress}

A key focus is the elucidation of disease processes and management protocols resulting in improved outcomes for the patient.The manuscript management system is completely online and includes a very quick and fair peer-review system. Visit http://www.dovepress.com/ testimonials.php to read real quotes from published authors. 